\title{
Seasonal changes of the copper level in shore crabs Carcinus mediterraneus
}

\author{
M. Devescovi, С̌. Lucu \\ Institute Ruder Bošković, Center for Marine Research Rovinj, 52210 Rovinj, Croatia
}

\begin{abstract}
Seasonal changes in copper content of the shore crab Carcinus mediterraneus Csrn. (whole crab, haemolymph, hepatopancreas and exoskeleton) were studied to establish patterns and to examine fluctuations in the population. A significant decrease in copper content in the haemolymph and hepatopancreas and an increase in the copper space (taken as an estimation of the haemolymph volume) occurred in winter. These changes are closely related to the drops in the protein and copper haemolymph concentrations of the winter crab populations when their activities and food intake are significantly decreased. The copper space strongly correlates with the haemolymph copper content and with the haemolymph copper concentration. On the basis of the haemolymph copper determinations a model of the copper space is described.
\end{abstract}

KEY WORDS: Copper content Copper space Seasonalvariations Carcinus mediterraneus

\section{INTRODUCTION}

Numerous studies have dealt with the physiological role of copper as a constituent of the haemocyanin fraction in crustaceans. Copper distributions in the tissues and organs of decapod Crustacea were described in detail by Bryan (1968). Changes of the copper level in decapods are related to the moulting cycle and to nutritional stage (see review by Depledge \& Bjerregaard 1989). Fluctuations of haemolymph copper and protein concentrations are linked with crustacean blood volume changes, the haemolymph volume decreasing in Penaeus spp. (Smith \& Dall 1982) and in Carcinus maenas (Bjerregaard 1990) as haemolymph protein concentrations increase. Changes in haemolymph volume and protein concentrations are consequently related to the moulting cycle and food supplies (Smith \& Dall 1982). The influence of the moulting cycle on the variability of $\mathrm{Cu}$ composition and metallothionein concentration in the haemolymph and hepatopancreas has been studied in the blue crab Callinectes sapidus (Engel 1987). The effect of feeding and starvation on the copper content and concentration of haemocyanin in crustacean haemolymph has also been studied, under laboratory conditions (Djangmah 1970, Hagerman 1983).
However, investigations of the seasonal fluctuations in copper content and the dependence of the copper content on haemolymph volume in marine and brackish-water Crustacea have rarely been carried out. The present study investigates seasonal changes in the copper content and their relationship with haemolymph copper space in the shore crab Carcinus mediterraneus Csrn. The copper space as an estimation of blood volume is the ratio of total crab haemolymph copper content to haemolymph concentration.

\section{MATERIAL AND METHODS}

Shore crabs Carcinus mediterraneus were caught every 3 mo throughout the year 1992-1993 (August and November 1992, February and May 1993) in the northern Adriatic Sea from the beaches of the Istrian peninsula in the vicinity of Rovinj (Croatia). In this region the copper concentration in the seawater is relatively low during the course of a year $(0.25 \pm 0.04 \mathrm{\mu g}$ $1^{-1}$; M. Devescovi pers. comm.), indicating a nonpolluted environment. Adult intermoult male specimens with a carapace width of 4 to $5 \mathrm{~cm}$ were collected according to the method of Drach \& Tchernigovtzeff (1967). 
Immediately after delivery, the crabs were weighed. The haemolymph samples (about $300 \mu l$ ) were withdrawn by severing the arthrodial membrane of the last walking leg of quiescent crabs and transferring the samples to preweighed Eppendorf micro test tubes. An aliquot of $100 \mu l$ haemolymph was taken for protein concentration analyses and the remainder was used for copper determination. After haemolymph treatment with $1 \%$ detergent SDS (sodium dodecyl sulphate) $(100 \mu l$ haemolymph $+100 \mu 10 \%$ SDS $+800 \mu$ distilled water) and appropriate dilution, the haemolymph protein concentration was determined spectrophotometrically at $562 \mathrm{~nm}$ wavelength by Pierce BCA protein assay (No. 23225 and 23220; Smith et al. 1985). Immediately after haemolymph collection, the crabs were frozen at $-25^{\circ} \mathrm{C}$ and stored in plastic bags before further examination. For copper determination each haemolymph sample was dried at $80^{\circ} \mathrm{C}$ and digested with $200 \mu \mathrm{l}$ of acid mixture $\left(\mathrm{HNO}_{3}: \mathrm{H}_{2} \mathrm{SO}_{4}=4\right.$ volumes: 1 volume; Suprapur, Merck Chemicals) according to the methods described by Sperling \& Bahr (1979). The hepatopancreas was dissected from the frozen specimens (25 specimens per season) whereas the carapace was separated from 5 crabs per sample. Separated parts of the crabs (hepatopancreas, whole crab without hepatopancreas and carapace) were dedicated completely for copper determinations. Six exuviae of freshly moulted crabs collected during a winter period were separated into gills, carapace, and the rest of the exuviae. All dissected parts were digested by boiling concentrated $\mathrm{HNO}_{3}$ in Kjeldahl flasks (150 ml $\mathrm{HNO}_{3}$ for the rest of the crab and the rest of the exuviae, 20 to $40 \mathrm{mI} \mathrm{HNO}_{3}$ for the hepatopancreas, carapace, carapace exuviae and gill exuviae). The digests were then made up volumetrically to $500 \mathrm{ml}$ (rest of the crab and rest of the exuviae) or $100 \mathrm{ml}$ (other parts). Dilutions of tissue digests were made with triple-distilled water
(Quartz distillation apparatus) for copper determinations.

After appropriate dilution of samples, copper determination was performed with a Perkin-Elmer 400 atomic absorption spectrophotometer at $324.7 \mathrm{~nm}$ wavelength (halogen lamp compensation, slit $0.7 \mathrm{~nm}$ ) The atomizer was a Perkin-Elmer graphite furnace (HGA 500) supplied with a L'vov platform (uncoated tube) protected by argon gas. Tissue copper content $(\mu \mathrm{g})$ was adjusted to an equivalent of $100 \mathrm{~g}$ wet wt crab to allow interspecimen comparison. The total crab copper content is the sum of copper contents in the rest of the crab, hepatopancreas, carapace and haemolymph samples. The copper content in the exoskeleton was determined from the experimental finding that the copper content of the carapace is $12.3 \%$ of the total exoskeleton copper content (for more details see 'Results'). The haemolymph copper content was estimated by subtracting the copper content of the exoskeleton (seasonal mean estimation) from the rest of the crab, which includes the haemolymph sample copper content.

Copper space in the shrimp Penaeus spp. was calculated as a ratio of the estimated haemolymph copper content (determined after dissection of the hepatopancreas) and the haemolymph copper concentration (Smith \& Dall 1982). In this work the copper content was estimated in a similar way, however the haemolymph copper content was additionally corrected for the exoskeleton copper content. Consequently, the experimental definition of the copper space described in this work is as follows:

$$
\text { Copper space }=\frac{C u_{\mathrm{crab}}-\left(C u_{\mathrm{hep}}+C u_{\mathrm{exos}}\right)}{C C u_{\text {hem }}}
$$

where $C u_{\text {crab }} C u_{\text {hep }}, C u_{\text {exos }}$ is total copper $(\mu g)$ content in the whole crab, hepatopancreas, and exoskeleton,

Table 1 Carcinus mediterraneus. Seasonal changes of total copper content in haemolymph, hepatopancreas, exoskeleton and whole crab (all data are referred to $100 \mathrm{~g}$ of crab wet wt) as well as of haemolymph copper and protein concentrations and copper space. Data are mean \pm SD of 25 measurements, except those for total copper content of exoskeleton where mean \pm SD of 5 estimations is given. Superscripts indicate that given values differ significantly from ${ }^{d}$ August, "November, ${ }^{\prime}$ February, ${ }^{m}$ May at the $p<0.01$ level or, if in brackets, at the 0.05 level on the basis of the Tukey HSD test

\begin{tabular}{|c|c|c|c|c|}
\hline & August & November & February & May \\
\hline \multicolumn{5}{|l|}{ Copper content $(\mu \mathrm{g})$ in: } \\
\hline Haemolymph & $1656 \pm 269^{n l}$ & $1371 \pm 285^{\mathrm{d}(\mathrm{m} / \mathrm{j}}$ & $1273 \pm 281^{\mathrm{am}}$ & $1601 \pm 297^{(n) !}$ \\
\hline Hepatopancreas & $403 \pm 143^{n f m}$ & $265 \pm 134^{d}$ & $213 \pm 100^{\circ}$ & $237 \pm 106^{a}$ \\
\hline Exoskeleton & $175 \pm 24$ & $189 \pm 20$ & $157 \pm 26$ & $180 \pm 28$ \\
\hline Whole crab & $2235 \pm 350^{n f}$ & $1785 \pm 344^{a}$ & $1642 \pm 316^{d m}$ & $2018 \pm 340^{\prime}$ \\
\hline \multicolumn{5}{|l|}{ Haemolymph } \\
\hline Copper conc. ( $\mu g g^{-1}$ wet $\left.w t\right)$ & $85 \pm 30^{\text {nfími }}$ & $56 \pm 22^{\text {म }}$ & $48 \pm 21^{d}$ & $65 \pm 25^{(a)}$ \\
\hline Protein conc. (mg g $\mathrm{g}^{-1}$ wet wt) & $50 \pm 16^{n t}$ & $35 \pm 13^{\circ}$ & $30 \pm 12^{a m}$ & $45 \pm 14^{f}$ \\
\hline $100 \times$ copper conc/protein conc. & $0.170 \pm 0.029^{m}$ & $0.163 \pm 0.031$ & $0.160 \pm 0.028$ & $0.144 \pm 0.023^{d}$ \\
\hline Copper space ( $\%$ of wet wt) & $21 \pm 6^{(n) f(x) 1)}$ & $27 \pm 7^{(a)}$ & $30 \pm 8^{d}$ & $26 \pm 6^{(a)}$ \\
\hline
\end{tabular}


respectively, and $\mathrm{Cu}_{\mathrm{hem}}$ is the haemolymph copper

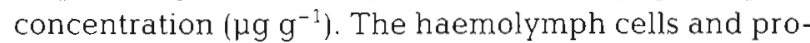
teins will be included in the copper space calculations; haemolymph copper concentration $\left(\mu \mathrm{g} \mathrm{g}^{-1}\right)$ measured includes haemolymph constituents, i.e. blood cells and proteins. In this study the copper content was related to the $100 \mathrm{~g}$ wet wt crab and therefore the resulting value is a percentage of the crab wet wt.

\section{RESULTS}

During the sampling period the mean values of the haemolymph, hepatopancreas and whole crab copper contents differed significantly (Table 1). Maximum values were reached in summer (August) and minimum values in winter (February) whereas in November and May intermediate values were obtained. The estimated copper content of the crab exoskeleton did not show any significant seasonal differences. The haemolymph copper and protein concentrations showed similar patterns to the haemolymph, hepatopancreas and whole crab copper contents. Also, the mean values of the copper space were significantly different. The minimum value was reached in summer and the maximum in winter (Table 1).

The copper content of the crab exoskeleton was estimated by means of the seasonally measured copper content of the carapace, the values of which were multiplied by the factor estimated empirically. We assumed that there is no difference in the copper distribution between the different parts of the exuviae and the intact intermoult exoskeleton. Taking into account that the carapace copper content represents $12.3 \%$ of the exuviae copper content, the values of the seasonally measured copper content of the carapace were multiplied by a factor of 8.13 to obtain an estimate of the copper content of the exoskeleton (Table 2). We assumed that most of the copper located in the exoskeleton is not involved in crab metabolism.

A linear relationship was observed between the copper content of the whole crab and the copper content of

Table 2. Carcinus mediterraneus. Copper distribution in some parts of the exuviae. Data are mean $\pm \mathrm{SD}$ of 6 measurements

\begin{tabular}{|lccc|}
\hline & Gill cuticle & Carapace & $\begin{array}{c}\text { Rest of the } \\
\text { exuviae }\end{array}$ \\
\hline $\begin{array}{l}\text { \% of the exuviae } \\
\text { dry wt }\end{array}$ & $2.4 \pm 0.2$ & $17.7 \pm 0.6$ & $81.0 \pm 2.3$ \\
$\begin{array}{l}\text { Copper conc. } \\
\text { ( } \mu^{-1} \text { dry wt) } \\
\% \text { of the exuviae } \\
\text { copper content }\end{array}$ & $21.3 \pm 5.4$ & $12.3 \pm 3.4$ & $66.4 \pm 5.7$ \\
\hline
\end{tabular}

the haemolymph (Fig. 1a). The total copper content of the hepatopancreas increased linearly with the increases of the copper contents in the whole crab (Fig. 1b). Moreover, the copper content of the hepato-
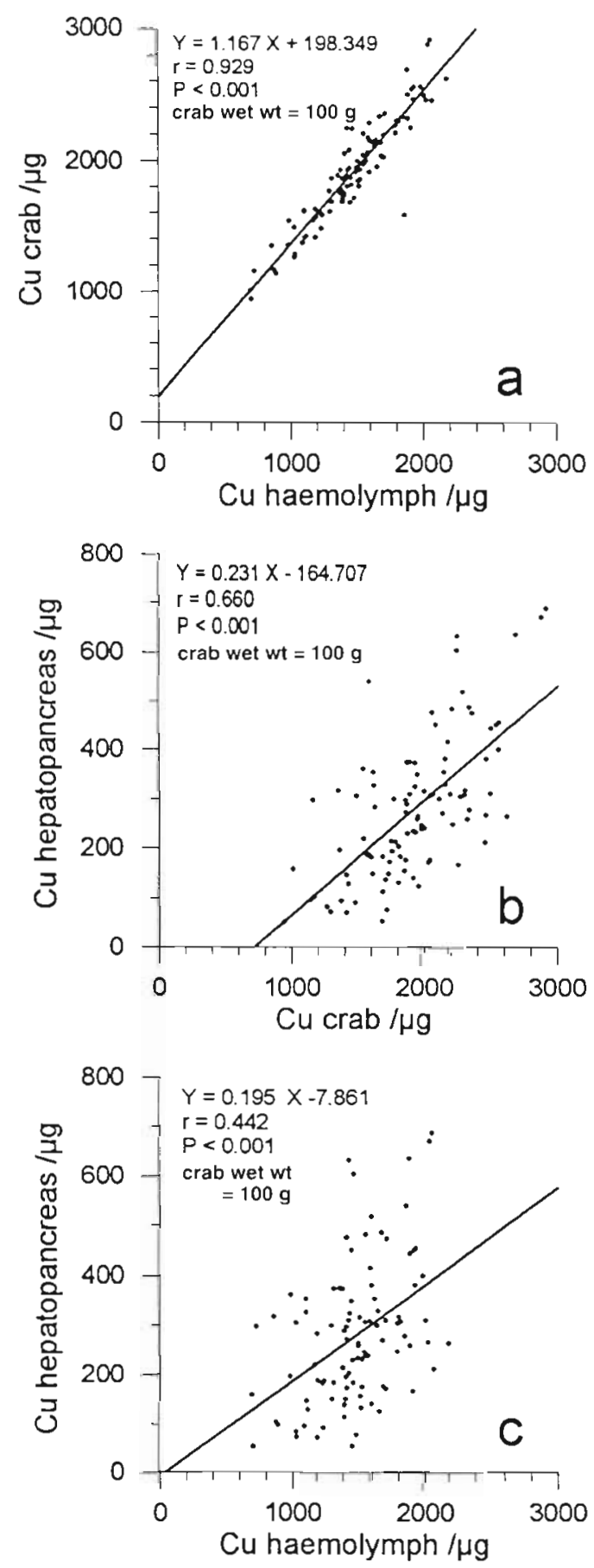

Fig. 1. Carcinus mediterraneus. Copper content relationship of (a) whole crab and haemolymph; (b) hepatopancreas and whole crab; (c) hepatopancreas and haemolymph. Individual values for 100 crabs ( 25 crabs per season) are expressed per $100 \mathrm{~g}$ wet wt of crab 


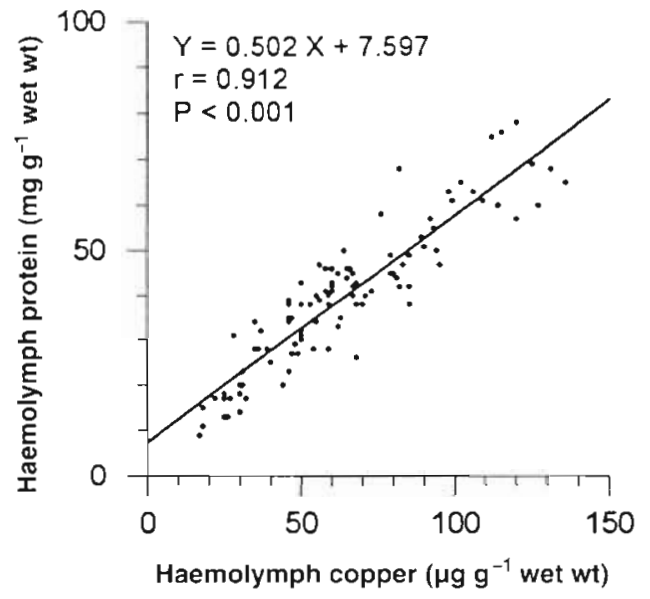

Fig. 2. Carcinus mediterraneus. Relationship between haemolymph protein and copper concentration. Samples were taken seasonally ( 25 crabs per season) from 100 crabs
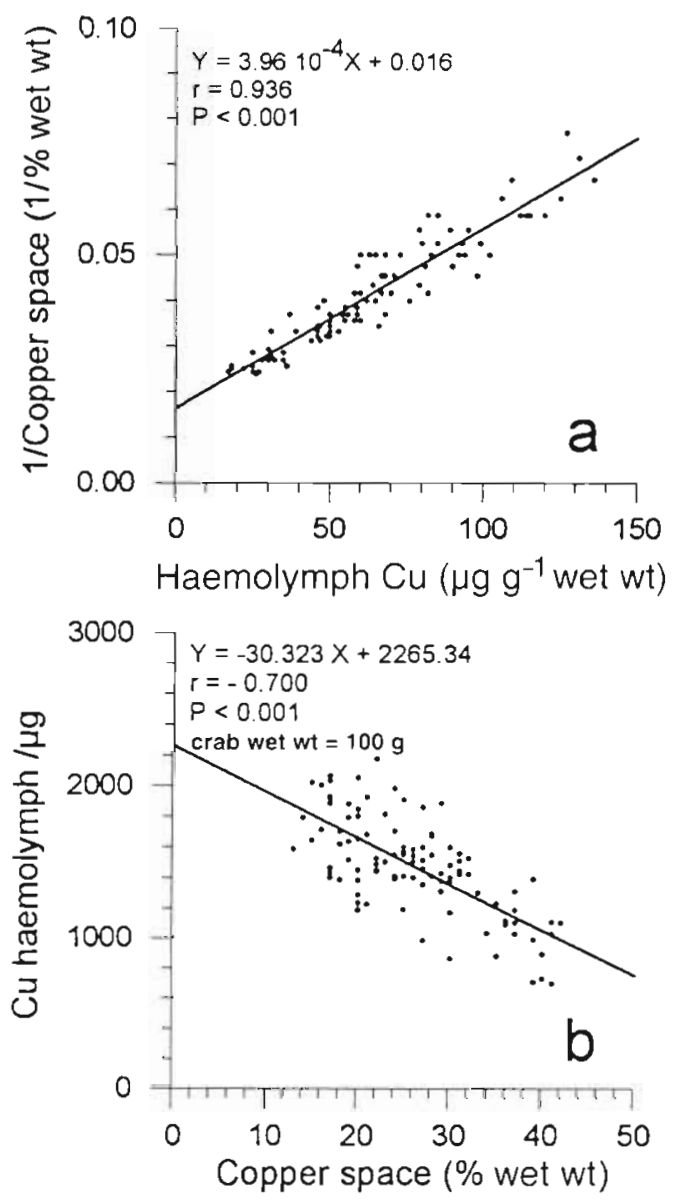

Fig. 3. Carcinus mediterraneus. Relationship between (a) reciprocal of the copper space and the haemolymph copper concentration, and (b) between the haemolymph copper content (expressed per $100 \mathrm{~g}$ wet wt of crab) and the copper space in 100 crabs collected seasonally in equal numbers $(n=25)$ pancreas increased linearly with the copper content of the haemolymph (Fig. 1c). The linear relationship between the protein and copper concentrations in Carcinus mediterraneus haemolymph is shown in Fig. 2.

The reciprocal copper space versus haemolymph copper concentration showed that a decrease in the copper space is accompanied by an increase in the haemolymph copper concentration and may be used to predict the copper space from the haemolymph copper concentration (Fig. 3a). Moreover, an inverse linear relationship was found between the haemolymph copper content and the copper space (Fig. 3b). Both relations shown in Fig. 3 can be mathematically transformed as:

$$
\text { Copper space }=k V /(k+c C u)
$$

where $k$ is the specific increase in the haemolymph copper content, $V$ is the internal crab volume, which includes crab extracellular space and existing tissues and organs, and $\mathrm{cCu}$ is the haemolymph copper concentration $\left(\mu \mathrm{g} \mathrm{g}^{-1}\right)$. Estimates for $k$ are 40 and $30 \mu \mathrm{g} \mathrm{Cu}$ per $1 \mathrm{~g}$ decrease of the copper space, and for $V$ are 63 and $76 \%$ of wet wt, from Fig. $3 a \& 3 b$, respectively.

\section{DISCUSSION}

The seasonal copper variations of the shore crab Carcinus mediterraneus demonstrate that copper space is significantly related to haemolymph copper content and concentration. We suggest that during winter the decreases in the haemolymph copper content and the subsequent increase of the haemolymph copper space were caused by the nutritional status of the crab. A decrease in body burden of the copper was observed following a decrease in activity and feeding of the crabs during winter. Decreases in the food intake during winter might be accompanied by decreases in the serum protein level in the haemolymph, reflecting the crab's nutritional status, Our results agree well with those of Engel \& Brouwer (1987), who likewise showed that copper and haemocyanin concentrations in the haemolymph of the blue crab Callinectes sapidus are significantly higher in summer than in winter populations. However, the copper content of the exoskeleton did not show any seasonal variations (Table 1). The mean value of the exoskeleton copper content in the course of the year, $175 \mu \mathrm{g}$. expressed on the basis of a $100 \mathrm{~g}$ wet wt crab, which includes copper content of the gill cuticle, is approximately less than twice the content of the Carcinus maenas exoskeleton described by Depledge (1989) and Depledge \& Bjerregaard (1989). This difference could be explained by the fact that the concentration of 
copper in the exoskeleton of C. mediterraneus is about $5 \mu \mathrm{g} \mathrm{g}^{-1}$ dry $w \mathrm{t}$, i.e. less than twice the concentration found in the crab $C$. maenas. Our results have shown that the mean values of the copper space fluctuate during the year within a range of 21 to $30 \%$ of wet wt.

Seasonal copper space fluctuations presented in this paper are within the range of the blood volume found in the shore crab Carcinus maenas (Binns 1969, Siebers \& Lucu 1973) and in other groups of Crustacea (Lockwood \& Inman 1973, Gleeson \& Zubkoff 1977). It is evident that the blood volume of decapods might be well characterized by the copper space since a considerable part of the crab copper content is located in the haemolymph. Almost all of the naturally available copper in the haemolymph is extracellularly bound in organo-metal complexes, predominantly in haemocyanin (Truchot 1978), and a partially Cu-bound metallothionein (Engel \& Brouwer 1987). Estimation of the copper space requires a distinction between the haemolymph copper content and the copper contained in the the rest of the body. In the shore crab C. maenas, which is closely related to the shore crab $C$. mediterraneus used in this study, most of the copper content is distributed in the haemolymph, hepatopancreas and exoskeleton and the rest, about $5 \%$, in the gills, muscles and residual soft parts (Depledge 1989). Therefore, the copper contents of the hepatopancreas and exoskeleton (copper contents of the gill cuticle are added to the copper contents of the exoskeleton) are taken into account (Eq. 1). However, the copper content of the muscle and the remaining soft parts was added to the haemolymph copper. Also, we assume that some portion of the haemolymph copper was present in the hepatopancreas and separated with it. In the shrimp Penaeus spp., about $2 \%$ of the $\mathrm{Cu}$ content of the hemolymph was left in the hepatopancreas (Smith \& Dall 1982). Considering these sources of error, it is believed that the copper space measured in the present study is a good approximation of the haemolymph volume.

Several authors have demonstrated that the tissue concentration of copper alters markedly during moulting (Riegel \& Parker 1960, Zuckerkandl 1960, Truchot 1978, Nott \& Marvin 1986, Engel 1987) or in response to starvation (Djangmah 1970, Djangmah \& Grove 1970, Depledge \& Bjerregaard 1989), salinity stress (Boone \& Schoffeniels 1979) and pollution (Kerkut et al. 1961). In the polluted area of Southampton (UK) a marked monthly variation of the haemolymph and hepatopancreas copper concentrations of the shore crab Carcinus maenas was reported (Kerkut et al. 1961). Very high copper concentrations in the exoskeleton of the crabs from the Southampton area markedly exceeded the values of Bryan (1968) and those reported for Mediterranean crab carapaces (this study), supporting the statement of Kerkut et al. (1961) that crabs lived in a polluted area. The crabs from nonpolluted areas used in this study were in the intermoult phase (C4). The locally collected population of the shore crabs $C$. mediterraneus moults in the period November to February. Most of the local male population of crabs which were collected with carapace width 40 to $50 \mathrm{~mm}$ were in the stage when ecdysis is rare. Therefore the changes should most probably be attributed to the nutritional status of the animals. The large amount of evidence on the variations in the volume as well as the copper and protein concentrations in the decapods' haemolymph has been described (see review by Depledge \& Bjerregaard 1989), however the functional meaning of these variations has not been considered.

The seasonal variations in the copper level for the Carcinus mediterraneus described in this paper can be attributed to the metabolic reactions induced by nutritional status. Tissue growth compresses the extracellular space, resulting in an increase of the copper and protein concentrations in the haemolymph. Proportional to the increase in tissue weight, new quantities of copper and proteins (haemocyanin) are stored in the haemolymph, additionally increasing their concentration. In winter during the crabs' malnutrition the copper space expands due to the tissues' increased catabolic processes and a proportional amount of the haemocyanin is degraded. We have estimated the rate of increase (decrease) of the haemolymph copper content for the 30 and $40 \mu \mathrm{g} \mathrm{Cu} \mathrm{g} \mathrm{g}^{-1}$ of the decrease (increase) of the copper space.

These estimations are related to the internal crab volumes of the 63 and $76 \%$ of crab wet wt, respectively (Fig. 3a, b). Eq. (2) has to be considered as a first approximation of the model describing the changes of the Carcinus mediterraneus blood and tissue volumes as a function of the haemolymph copper concentration. For this purpose improved approaches to differentiating the copper distribution with regard to enzymatic copper demand (White \& Rainbow 1985, Depledge 1989) and the extracellular space are desirable in the future. The extracellular space in Crustacea is divided into 2 distinct compartments, the blood and the extracellular space, into which haemocyanin cannot penetrate (Flemister 1958, Robertson 1960, Zukerkandl 1960 , Smith \& Dall 1982). It is assumed that the extracellular space of $C$. mediterraneus includes plasma, interstitial fluids around the cells, and perhaps the rest of the fluid in the gut and the antennal gland. Variations of the non-haemocyanin-containing extracellular space in the fixed internal crab volume can cause changes in the haemolymph haemocyanin concentration at a constant haemolymph copper content. Therefore, for a better understanding of the copper space 
and blood volume variations, it will be crucial in the future to study non-haemocyanin-containing compartments of the extracellular space.

It has been demonstrated previously that the haemolymph protein concentration might be used to predict haemolymph volume (Smith \& Dall 1982) and muscle weight (Stewart et al, 1967). On the basis of the measured haemolymph copper concentration, Eq. (2) predicts the copper space changes induced by the different nutritional regimes when the exoskeleton is completely calcified. Predictions for 2 extreme values of the haemolymph copper concentrations (25 and $100 \mu \mathrm{g} \mathrm{g}^{-1}$ ) in Carcinus mediterraneus will be demonstrated by using the mean values of the constants expressed in Eq. (2) ( $k=35 \mu \mathrm{g} \mathrm{Cu}^{-1} ; V=70 \%$ of wet wt). For a haemolymph copper concentration of $25 \mu \mathrm{g}$ $\mathrm{g}^{-1}$ we calculate a copper space of $41 \%$ of wet wt, while the tissues and organs amount $29 \%$ of wet wt (internal crab volume minus copper space). The haemolymph copper content is $1025 \mathrm{\mu g}$ per $100 \mathrm{~g}$ wet wt (volume $\times$ concentration) and the whole crab copper content is $1428 \mu \mathrm{g}$ per $100 \mathrm{~g}$ wet wt (Fig. 1a). In another example, when the haemolymph copper concentration is $100 \mu \mathrm{g} \mathrm{g}^{-1}$, the calculated copper space will amount to $18 \%$ of wet wt; tissue and organs amount to $52 \%$ of wet wt and the haemolymph and whole crab copper contents are 1800 and $2332 \mu \mathrm{g}$ per $100 \mathrm{~g}$ wet $w$, respectively.

Acknowledgements. The authors thank Prof. David Towle for his criticism during the course of the study.

\section{LITERATURE CITED}

Binns, R. (1969). The physiology of the antennal gland of Carcinus maenas (L.). II Urine production rate. J. exp. Biol. 51: $11-16$

Bjerregaard, P. (1990). Influence of physiological condition on cadmium transport from haemolymph to hepatopancreas in Carcinus maenas. Mar. Biol. 106: 199-209

Boone, W R., Schoffeniels, E. (1979). Hemocyanin synthesis during hypo-osmotic stress in the shore crab Carcinus maenas (L.). Comp. Biochem. Physiol. 63B: 207-214

Bryan, G. W. (1968). Concentrations of zinc and copper in the tissues of decapod crustaceans. J. mar. biol. Ass. U.K. 48: 303-321

Depledge, M. H. (1989). Re-evaluation of metabolic requirements for copper and zinc in decapod crustaceans. Mar environ. Res. 27: 115-126

Depledge, M. H., Bjerregaard, P. (1989). Haemolymph protein composition and copper levels in decapod crustaceans. Helgoländer Meeresunters. 43: 207-223

Djangmah, J. S. (1970). The effects of feeding and starvation and copper in the blood and hepatopancreas, and on blood proteins of Crangon vulgaris (Fabricius). Comp. Biochem. Physiol. 32: 709-731

Djangmah, J. S., Grove, D. J. (1970). Blood and hepatopancreas copper in Crangon vulgaris (Fabricius). Comp Biochem. Physiol. 32: 733-745

This article was submitted to the editor
Drach, P., Tchernigovtzeff, C. (1967). Sur la méthode de détermination des stades d'intermue et son application générale aux crustacés. Vie Milieu 18: 595-609

Engel, D. W. (1987). Metal regulation and molting in the blue crab. Callinectes sapidus: copper, zinc, and metallothionein. Biol. Bull. 172: 69-82

Engel, D. W., Brouwer, M. (1987). Metal regulation and molting in the blue crab, Callinectes sapidus: metallothionein function in metal metabolism. Biol. Bull. 173: 237-249

Flemister, L. J. (1958). Salt and water anatomy, constancy and regulation in related crabs from marine and terrestrial habitats. Biol. Bull mar. biol. Lab. Woods Hole 115: 180-200

Gleeson, R. A., Zubkoff, P. L. (1977). The determination of hemolymph volume in the blue crab, Callinectes sapidus, utilizing ${ }^{14} \mathrm{C}$-thiocyanate. Comp. Biochem. Physiol. 56: 411-413

Hagerman, L. (1983). Haemocyanin concentration of juvenile lobster (Homarus gammarus) in relation to moulting cycle and feeding conditions. Mar. Biol. 77: 11-17

Kerkut, G. A., Moritz, P. M., Munday, K. A. (1961). Variations of copper concentrations in Carcinus maenas. Cah. Biol. mar. 11: 399-408

Lockwood, A. P. M., Inman, C. B. E. (1973). The blood volume of some amphipod crustaceans in relation to the salinity of the environments they inhabit. Comp. Biochem. Physiol. 44A: $935-941$

Nott, J. A., Marvin, L. J. (1986). Adaptation of a quantitative programme for the $x$-ray analysis of solubilised tissues as microdroplets in the transmission electron microscope: application to the moult cycle of the shrimp, Crangon crangon (L. ). Histochem. J. 18: 507-518

Riegel, J. A., Parker, R. A. (1960). A comparative study of crayfish blood volumes. Comp. Biochem. Physiol. 1 302-304

Robertson, J. D. (1960). Ionic regulation in the crab Carcinus maenas (L.) in relation to the moulting cycle. Comp. Biochem. Physiol. 1: 183-212

Siebers, D., Lucu, Č. (1973). Mechanisms of intracellular isosmotic regulation: extracellular space of the shore crab Carcinus maenas in relation to environmental salinity. Helgoländer wiss. Meeresunters. 25: 199-205

Smith, D. M., Dall, W. (1982). Blood protein, blood volume and extracellular space relationship in two Penaeus spp (Decapoda: Crustacea) J. exp. mar. Biol. Ecol. 63: 1-16

Smith, P. K., Krohn, R. I., Hermanson, G. T., Mallia, A. K., Garthner, F. H., Provenzano, M. D., Fujimoti, E. K., Goeke, N. M., Olson, B. J., Klenk, D. C. (1985). Measurement of protein using bicinchoninic acid. Analyt. Biochem. 150: $76-85$

Sperling, K. R., Bahr, B. (1979). Determination of heavy metals in sea water and marine organisms by flameless atomic absorption spectrophotometry. VIII. Digestion of biological materials. Z. Lebensm. Unters. Forsch. 168: 193-194

Stewart, J. E., Cornick, J. W., Foley, D. M., Li, M. F., Bishop, C. M. (1967). Muscle weight relationship to serum protein, hemocytes and hepatopancreas in the lobster, Homarus americanus. J. Fish. Res. Bd Can. 24: 2339-2354

Truchot, J. P. (1978). Variations de la concentration sanguine d'hémocyanine fonctionnelle au cours du cycle d'intermue chez le crabe Carcinus maenas (L.). Arch. Zool. exp. gén. 119: $265-282$

White, S. L., Rainbow, P. S. (1985). On the metabolic requirements for copper and zinc in molluscs and crustaceans. Mar. environ. Res. 16: 215-229

Zuckerkandl, E. (1960). Y a-t-il plus d'un 'espace extracellulaire' chez les crustacés décapodes? Cah. Biol. mar. 1 $25-35$ 